International Journal of Agriculture and Environmental Research

ISSN: 2455-6939

Volume: 06, Issue: 06 "November-December 2020"

\title{
RICE PRODUCTION ECONOMICS OF SUB-TROPICAL AGROECOLOGY IN SOUTHERN BHUTAN
}

\author{
${ }^{* 1}$ Tshering Tashi, ${ }^{2}$ Chezang Dendup \\ ${ }^{1,2}$ Agriculture Research and Development Centre (ARDC)- Samtenling \\ Department of Agriculture, Ministry of Agriculture and Forests, Bhutan \\ *Corresponding author
}

DOI: https://doi.org/10.51193/IJAER.2020.6602

\begin{abstract}
The objectives of this study were to assess the profitability of rice cultivation under the current cultivation practices through the determination of cost and return in Southern Bhutan. Using the multi-stage random sampling method, 300 farmers were included in the sample. The main tool used for data collection was a pre-tested semi-structured questionnaire. Budgeting techniques and descriptive statistics were used for analyzing the data. The study reveals that gross return was $\mathrm{Nu} .52500(\approx \mathrm{USD} 740)$ acre $^{-1}$ of rice cultivation from the investment of $\mathrm{Nu}$. $52434(\approx \mathrm{USD}$ 738.5). Thus, the gross margin was Nu. 1066 ( $\approx$ USD 15) which is equivalent to $2.1 \%$ of the total overall cost. The analysis shows that a benefit-cost ratio of 1.021 with break-even price and yield at $\mathrm{Nu} .69$ ( $\approx \mathrm{USD} 0.97) \mathrm{Kg}^{-1}$ and $735 \mathrm{Kg}$ milled rice respectively. Rice farming was found labour intensive and it accounts for $77 \%$ of the total cost whereas that of other costs constitutes only $13 \%$. Sensitivity analysis on the benefit-cost ratio shows that rice production is more sensitive to change in productivity and labor requirements than subsidy. Despite low productivity, soil fertility and crop management were found poor in southern Bhutan. Thus, the study recommends technical intervention such as farm mechanization and exploration of labor-saving technologies, adoption of high-yielding improved varieties, soil, and crop management. On the flip side, pertinent policy interventions like subsidies, compensation, and incentives are also important to make rice farming profitable.
\end{abstract}

Keywords: Total Variable Cost, Gross Margin, Benefit-Cost Ratio, Break-Even Point, Sensitivity Analysis.

\section{INTRODUCTION}

Bhutan is an agrarian country with about $62.2 \%$ of the total population living in rural areas depending on agricultural activities (Population and Housing Census of Bhutan [PHCB], 2017). 
International Journal of Agriculture and Environmental Research

ISSN: 2455-6939

Volume: 06, Issue: 06 "November-December 2020"

Rice is the preferred staple food grain and widely consumed cerealin Bhutan (Shresthra, 2003; Ghimiray, 2012) and the government has placed rice among six prioritized crops in the $12^{\text {th }}$ Five Year Plan (Department of Agriculture [DoA], 2019). The estimated annual per capita consumption of milled rice is 140 Kilograms (DoA, 2019), and on average $10 \%$ of annual household income is spent only on the rice (Living Standards Survey, 2017). Besides food, rice is also associated with Bhutanese culture, religion, and history. It is the main component of nine cereals (Dru nag gu) and is indispensable during rituals and ceremonies (Wangchuck, 2015). Currently, 31,574.01acres of wetland area under rice cultivation with a productivity of about 1.57 tonnesacre $^{-1}$ (Agriculture Statistics, 2019).

At present, rice self-sufficiency in Bhutan stands at $46.7 \%$ (DoA, 2019) which means more than $50 \%$ of the rice consumed in the country is imported. Although rice production and productivity increased by $10.7 \%$ and $12.7 \%$ respectively in 11 Five Year Plan (2013-2017) but the import was increased to 86,385 tonnes in 2017 from 78,014 tonnes in 2013 (Agriculture Statistics, 2017). Similarly, the import of rice increased to 84,584 tonnes in 2019 from 71,503 tonnes in 2018 with an increase of 18 percent despite the ardent government's effort to peruse rice self-sufficiency (Bhutan Trade Statistics, 2019). Besides the increasing domestic demand, rice is also a potential export agricultural commodity. In 2019, Nu. 14.66M revenue was generated through the export of rice (Bhutan Trade Statistics, 2019) indicating rice as an important crop for domestic consumption and export market.

An increase in domestic rice demand is coupled with increasing fallow land over the years as evidenced through an increase in national fallow land from 7820 acres in 2017 to 8957.87 acres in 2019 (RNR Statistics, 2019). This shows that the rice cultivation area is shrinking and rice producers are exiting rice farming. One such factor could be the weak competitiveness of domestic rice production with cheaper and widely accessible imported Indian rice in the market. Regardless of many constraints of mountainous agriculture in Bhutan, rice farming needs special attention as rice is often equated with national food security (Chhogyel et al, 2015). Therefore, it is important to understand key factors, driving forces, and limitations to map out the strategies to increase production and profitability.

It is difficult to substantiate if rice farming in Bhutan is a lucrative enterprise given the strong competition from cheaper imported rice. Hence, having an appropriate strategy for making rice production more economical is crucial. Study on rice production economics and investigate its profitability could be one such basic and important strategy to understand the economic aspects of rice farming in Southern Bhutan. It is also fundamental to generate baseline production economics to commercialize rice farming in Southern Bhutan which has the highest rice area in the country. Besides, understanding relative profitability between competing enterprises under a dynamic environment becomes important beyond scope of profit, breakeven yield, or output 
price (Dillon, 1993). There is a dearth of information on the production economics of rice in Bhutan though much attention has been given to increasing production and productivity. Therefore, this study was undertaken to determine the costs and returns from rice cultivation under current farming practices in southern Bhutan and to examine technological, policy, and institutional interventions required to further strengthen rice production in southern Bhutan. An attempt was also made to understand the sensitivity of rice farming in Southern Bhutan to guide strategies and policies pertaining to enhancing rice profitability in the region.

\section{MATERIALS AND METHODS}

\subsection{Study Area}

The study was conducted in Samtse and Sarpang districts which represent the largest rice production area in Southern Bhutan. A total of eight blocks was selected for the survey as shown in Table 1. Samtse and Sarpang districts have a total area of 1305 sq. km and 1946 sq. km respectively. Samtse has a farming population of 17458 with an overall population density of 48 per $\mathrm{km}^{2}$ while Sarpang has a farming population of 9001 with an overall population density of 24 $\mathrm{km}^{2}$ (RNR statistics, 2017). These districts constitute 20.1 percent of the rice production area in Bhutan with a total production of 15000 MT in 2017 (Agriculture statistics, 2017). The districts have a wide range of agro-ecological zones ranging from Wet subtropical (100-600m) to cool temperate (2600-3600m) of which most areas fall under humid subtropical (600-1200) and warm temperate (1800-2600m), (RNR census, 2019). Samtse receives an annual rainfall of $5763 \mathrm{~mm}$ with an average maximum temperature of 29 degrees and a minimum of 18.3 degrees while Sarpang receives an average annual rainfall of $5930 \mathrm{~mm}$ with a maximum of 27.6 and minimum of 20.6 degrees(NCHM, 2017).

Table 1: Surveyed Area

\begin{tabular}{lll}
\hline District & District & Rice Agro-ecological zone \\
\hline Samtse & Samtse \& Tashi Chhoeling & Low altitude \\
& Norgaygang \& Dophuchen & Mid Altitude \\
\cline { 2 - 3 } Sarpang & Chuzangang \& Serzhong & Low Altitude \\
& JimeChhoeling \& Dekiling & Mid Altitude \\
\hline
\end{tabular}

Low altitude rice $=160 \mathrm{~m}-600 \mathrm{~m}$, Mid altitude Rice $=>600 \mathrm{~m}-1500 \mathrm{~m}$ (Shrestha, 2003). 


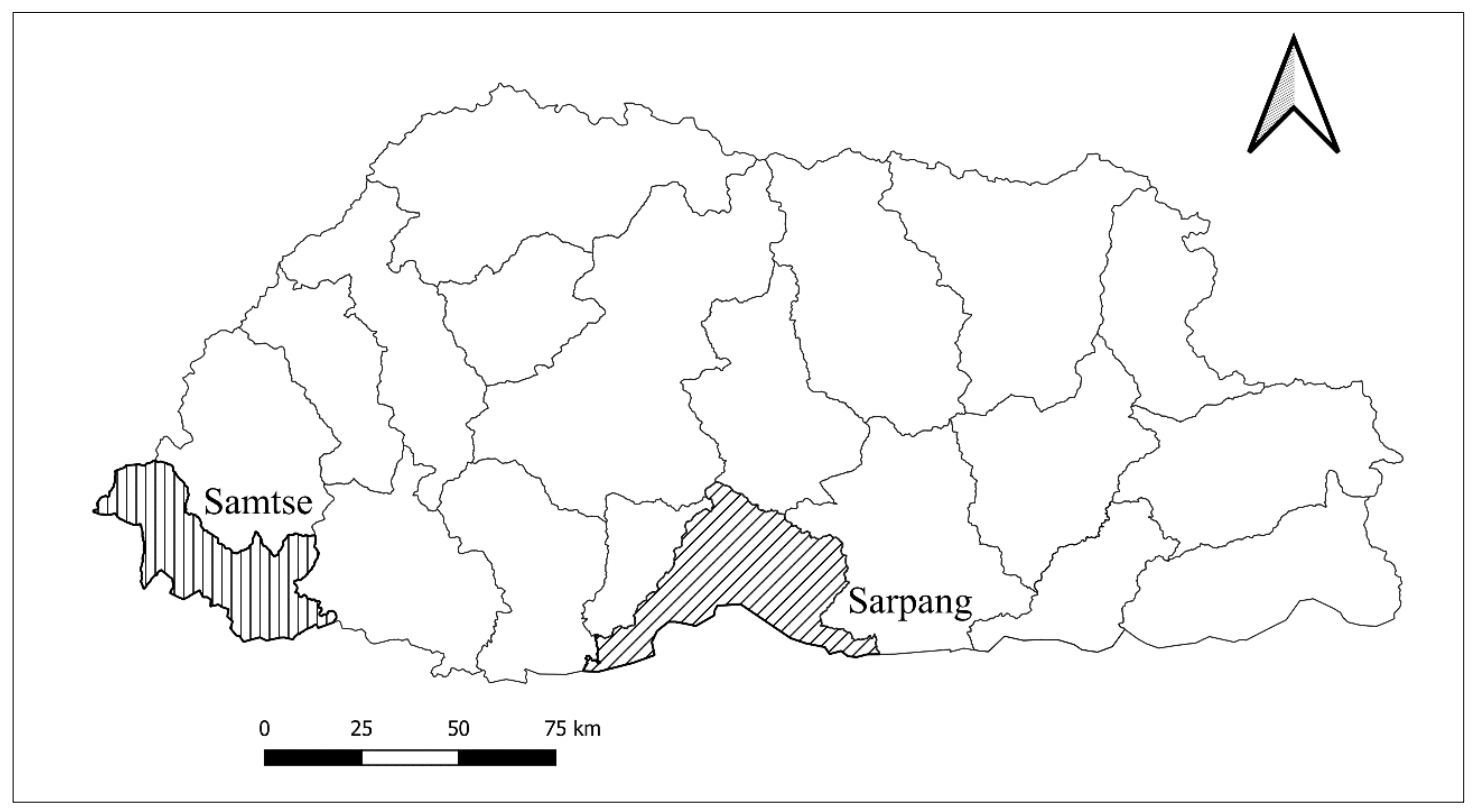

Fig 1: Bhutan showing the surveyed area

\subsection{Sampling and data collection}

Multistage sampling was followed to draw an inclusive representative sample for the study. In the first stage, two major rice-growing districts were selected purposefully from southern districts and then four blocks were selected from each district in the second stage based on production, cultivated area, and rice agro-ecological zone. The villages and households were then randomly selected from these blocks in consultation with Block Agriculture Office in the third stage. Further, 300 rice growers were randomly selected in the final stage of sampling of which, 55\% were from Samtse, and $45 \%$ from Sarpang. Data were collected using a pre-tested semi-structured questionnaire on cropping season 2019. The data on other related information was obtained from other available secondary sources. Data analysis was done using Excel Spreadsheet 2013.

\section{ANALYTICAL FRAMEWORK}

\subsection{Cost and Return Analysis}

The budgeting technique was used to calculate the cost and return acre ${ }^{-1}$ to study the profitability of paddy production. All costs and returns were computed in Bhutanese currency Ngultrum. The cost and return analysis carried out in this study adopted the concepts of Ciaianet al. (2013) \& Preedasak (2004) (as cited in Suwanmaneepong, S., Kerdsriserm, C., Lepcha, N., \& Cavite, H.) as follows: 


\section{Total Cost $($ TC $)=$ Total Fixed Cost $($ TFC $)+$ Total Variable Cost $($ TVC $)$}

TVC includes all the costs that vary with the level of production such as seed, fertilizer, labor, mechanical power, etc. No TFC was considered in this study since items including agricultural tools used by the farmers could last only for a production year. Both implicit and explicit costs were included wherein the cost of the family supplied labour and inputs were estimated by imputing the existing prevalent rate from the survey. The rental value of land is estimated by imputing land tax since the surveyed area has neither leased land nora formal payment system for land lease. Also, the cost of opportunities for the wetland is reported negligible in the ricegrowing season during the survey.

For return analysis gross return (GR) was computed as the total monetary value of rice by taking the average prevalent market price of rice. Profits or gross margin (GM) is computed as GRTVC, the Net return (NR) is computed as GR-TC, and the Benefit-Cost Ratio (BCR) is computed as GR/TC. To understand the level of production where net profit is zero, the calculation of Breakeven point concept is adopted from (Dillon, 1993) as follows:

For Yield: For the known price and cost, level of production where an enterprise would be having breakeven is given;

$Y_{\mathrm{i}} \frac{V C i+F C i+\pi i}{P i}$

For output price: For a known level of production, output price where an enterprise would be having breakeven is given;

$P_{\mathrm{i}} \frac{V C i+F C i+\pi i}{Y i}$

Where;

$Y_{i}=$ Yield of the commodity $i, P_{i}=$ Price of commodity $i, V C_{i}=$ Variable cost of production of commodity $i, F C_{i}=$ Fixed cost for production of commodity $i$.

Breakeven considerations to cover costs can be investigated by setting profits $\left(\pi_{\mathrm{i}}\right)$ to zero. All input and output prices are considered only farm gate rates thereby excluding the marketing cost and profits.

\subsection{Sensitivity Analysis}

To determine the consequences of specified changes in variables such as production volume, product price, input costs, and extent of subsidy, sensitivity analysis based on BC ratio was performed to study their relationships and also explore alternatives measures to increase the 
benefits from rice production. The concept was adopted from Abera1, Bekele, Assaye \& Melak, (2019).

\section{RESULTS AND DISCUSSION}

\subsection{Brief characteristics of surveyed farmers}

Famers in the sampled area practice an integrated farming system that includes crop production, livestock rearing, and agro-forestry for livelihood. They grow rice in the wetland during summer (May-Nov) and focuses on vegetables and maize, wheat and millets during winter and spring seasons. Commonly cultivated varieties of rice include BR 153, Bhur Ray Kaap, Bhur Kambja, Ranjeet, Choti Masino, Champa, Mama, and few varieties diffused from the porous border. The farmers practice subsistence farming with an average rice cultivated area of 1.5 and 1 acre in Sarpang and Samtse respectively. About $75 \%$ of farmers in Sarpang cultivated rice in less than 2.3 acres while that of Samtse was 1.5 acres. Nearly $3 \%$ of farmers of Sarpang cultivated paddy on more than four acres as shown in Fig.1.

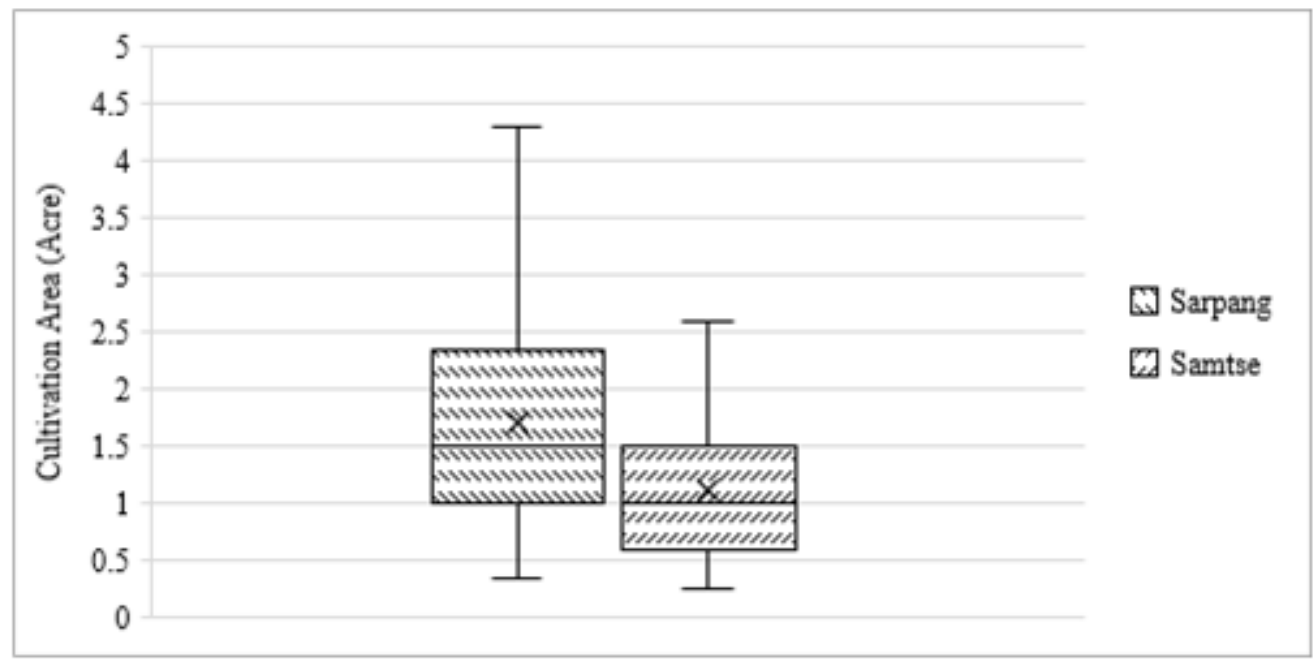

Fig 2: Whisker and box plot of cultivated area

Farm machinery use is not very common in these two districts. In Sarpang 30.5\% of farmers use farm machinery for paddy cultivation compared to $23.3 \%$ in Samtse. Farmers use draught animals for ploughing and puddling, and other operations were performed manually. The use of agrochemicals was very limited and farmers practice more or less natural farming. However, $18.4 \%$ of the farmers in Sarpang uses Butachlor to control the weeds in rice. 
International Journal of Agriculture and Environmental Research

ISSN: 2455-6939

Volume: 06, Issue: 06 "November-December 2020"

Table 2: Use of Farm Machinery and Agrochemicals

\begin{tabular}{lll|ll}
\hline \multirow{2}{*}{ Items } & \multicolumn{2}{c|}{ Samtse $(\mathrm{n}=159)$} & \multicolumn{2}{c}{ Sarpang $(\mathrm{n}=141)$} \\
\cline { 2 - 5 } Farm Machinery & Frequency & Percentage & Frequency & Percentage \\
\cline { 2 - 5 } use & 37 & 23.3 & 43 & 30.5 \\
Fertilizer use & 4 & 2.5 & 5 & 3.5 \\
Weedicides & 5 & 3.1 & 26 & 18.4 \\
PP chemicals & 1 & 0.6 & 1 & 0.7 \\
\hline
\end{tabular}

\subsection{Production Costs}

The analysis of the cost of paddy cultivation presented in Table 4 reveals the average cost of $\mathrm{Nu}$. $51434 \mathrm{acre}^{-1}$ in the region. The cost of production for one kilogram of milled rice was Nu. 41.15 and the finding is close to $\mathrm{Nu} .38$ and $\mathrm{Nu} .41$ for low altitude and mid-altitude respectively reported in National Cost of production for field and horticultural crops, (2020). Only variable cost is considered since the cost of production is calculated for one season.

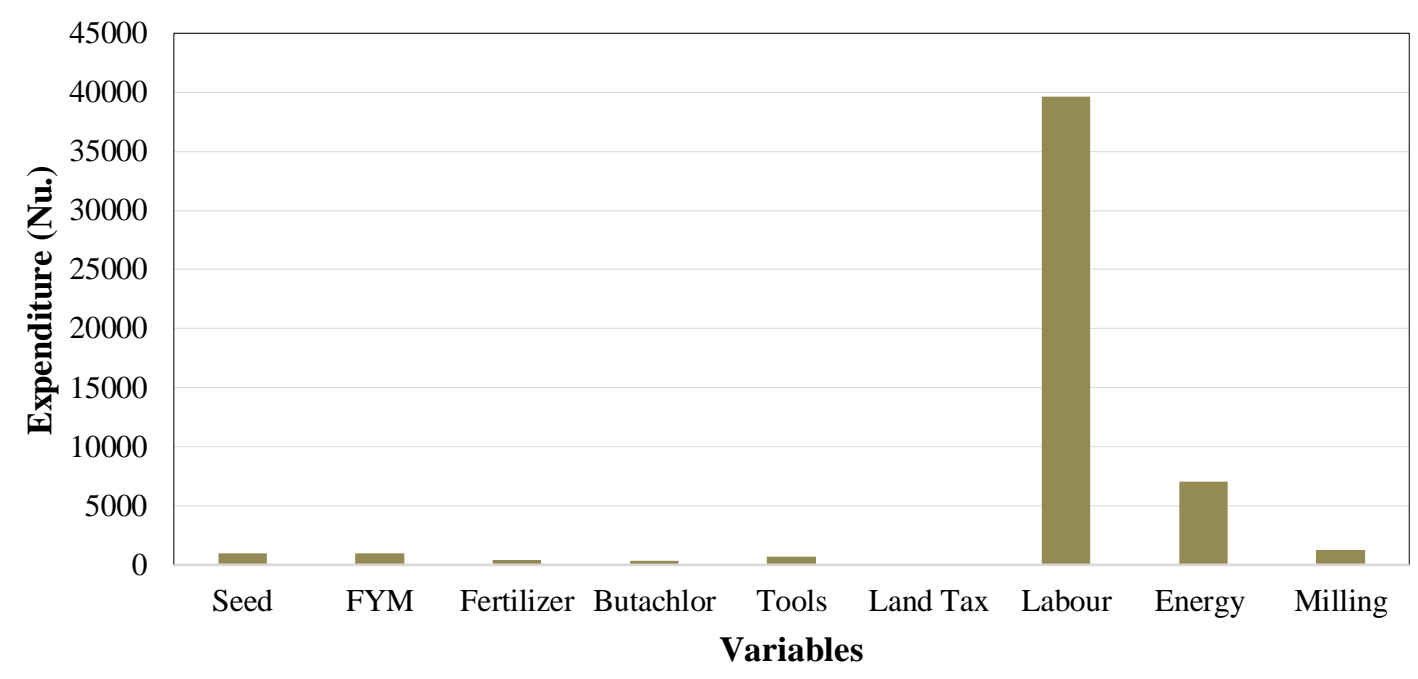

Fig 3: Expenditure on different variables 


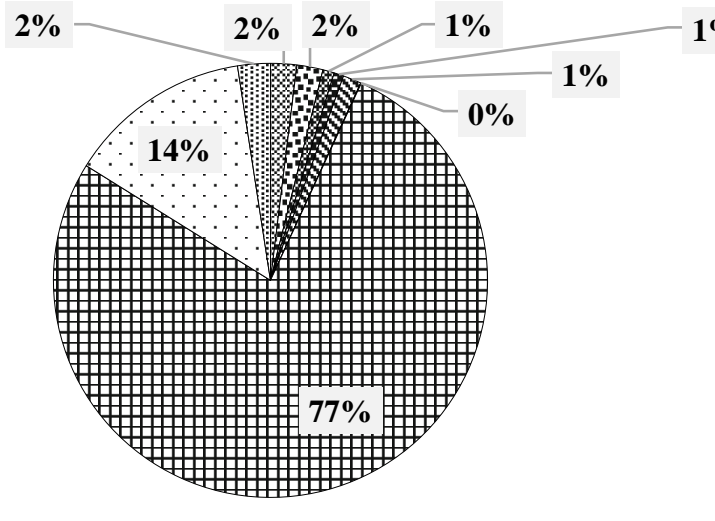

$1 \%$

\begin{tabular}{|c|c|}
\hline Seed & ⿴囗大 FYM \\
\hline Fertilizer & Butachlor \\
\hline \$ Tools & $\square$ Land Tax \\
\hline$\boxplus$ Labour & $\square$ Energy \\
\hline
\end{tabular}

Fig 4: Percent share of different cost

\subsubsection{Labour Requirement and Labour Costs}

For one acre of rice cultivation, 88 man-days are required including the nursery operation which costs $\mathrm{Nu} .39600$ at the prevailing average wage rate $\mathrm{Nu} .450$ per man-day. The finding is very close to 97 man-days recorded in the survey report (Karma \& Ghimiray, 2003). The maximum labour requirement was recorded during transplanting (15-man days) and minimum for irrigation ( 2 man-days). Labour cost constitutes the largest share of the cost (77\%) of the total costs incurred in rice cultivation. Less than $25 \%$ of the farmers engaged farm machinery in paddy cultivation while the remaining farmers used draught animals for field preparations like ploughing and puddling. The average energy cost (average cost of hired machinery and draught power) was $\mathrm{Nu} .7050 \mathrm{acre}^{-1}$ which contributes $14 \%$ to the total cost.

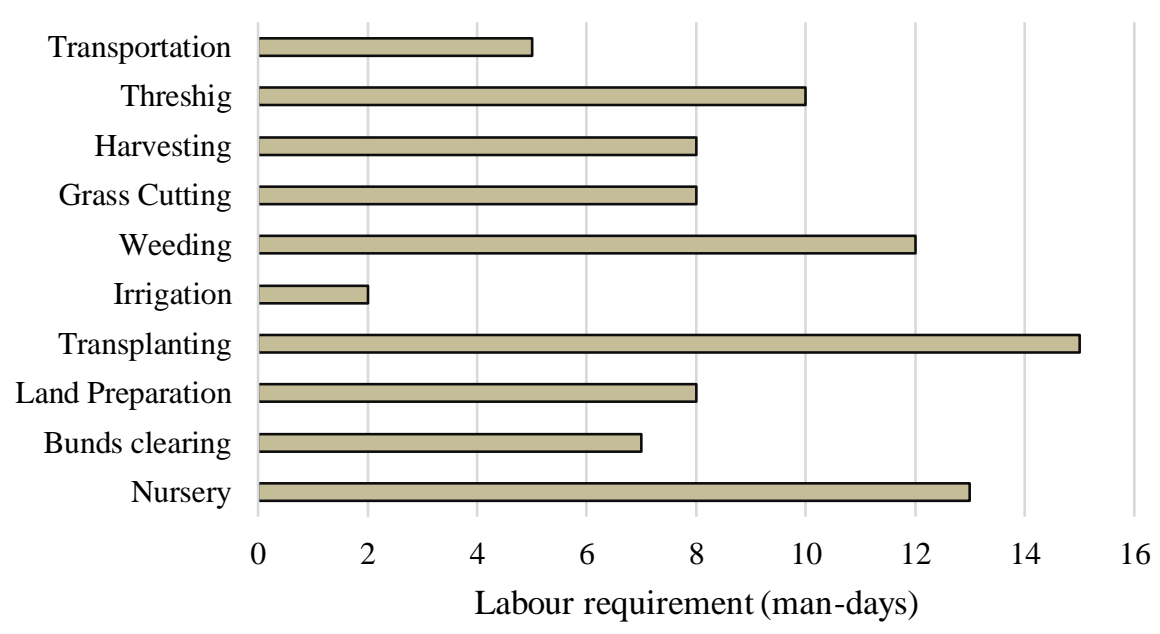

Fig 5: Labour requirement for different operations 
International Journal of Agriculture and Environmental Research

ISSN: 2455-6939

Volume: 06, Issue: 06 "November-December 2020"

\subsubsection{Materials Costs and Post-Harvest Cost}

Materials cost which includes seed, FYM, fertilizer, Butachlor, tools, and land tax was Nu.3534 and it constitutes only $6.87 \%$ of the total cost. The average FYM application acre ${ }^{-1}$ was 1 tonne and only $3 \%$ of the farmers used fertilizers. About $18.4 \%$ and $3.1 \%$ of farmers in Sarpang and Samtse respectively use Butachlor to control weeds. For milling, farmers pay either in kind or cash as milling charge but for conclusive analysis, cash payment is considered in this study. $\mathrm{Nu}$. 1250 was the cost incurred for milling 1.25 tonnes of paddy by taking the average prevailing milling charge of Nu.1000 tonne ${ }^{-1}$.

\subsection{Outcome and Net Return}

As per the Agriculture Statistics (2017, 2018 \&2019), 1.25 tonnes is the average paddy yield $\mathrm{acre}^{-1}$ in the surveyed blocks. Considering the milling recovery at 60 percent, the total milled rice production comes 0.75 tonne acre $^{-1}$. During the survey, farmers reported that they don't earn any income from the sale of paddy byproducts. The byproducts like straw, rice bran, the husk is either used as animal feed or shared with neighbors at free of cost. So, considering the opportunity cost of byproducts as zero, the gross return is counted only from the value of milled rice. Taking the prevailing farm gate price of $N u .70 \mathrm{~kg}^{-1}$ of rice, the gross return from the sale of 0.75 tonnes of milled rice was $\mathrm{Nu}$. 52500. Thus, the gross margin is $\mathrm{Nu} .1066 \mathrm{acre}^{-1}$ which constitutes only $2 \%$ of the total revenue earned with a benefit-cost- ratio of 1.021 .

Further, break-even price was Nu. $69 \mathrm{~kg}^{-1}$ whereas break-even production was $735 \mathrm{Kgacre}^{-1}$. This shows that farmers will neither make a profit nor be in loss up to rice production $735 \mathrm{Kg}_{\text {acre }}{ }^{-1}$ or farm gate price at $\mathrm{Nu} .69 \mathrm{~kg}^{-1}$. The break-even analysis shows that the gross margin of rice production is highly vulnerable to a decrease in yield or a drop in selling price. This implies that the sale of every $100 \mathrm{~kg}$ of rice makes a profit of Nu.2.1. Thus, analysis shows that rice farming is not remunerative in districts under this study. A similar study conducted in the neighboring Indian state of Assam also revealed a negative return at the macro level for rice production (Pathok P, Deka N 2019). This study agrees with the findings of Suwanmaneepong et al., (2020) and Manikandan et al., (2018) in Thailand and India respectively where they reported low net return from paddy cultivation. 
International Journal of Agriculture and Environmental Research

ISSN: 2455-6939

Volume: 06, Issue: 06 "November-December 2020"

Table 3: Cost of cultivation

\begin{tabular}{|c|c|c|c|c|c|}
\hline Outputs/ inputs & Unit & Quantity & Price (Nu. /Unit) & $\begin{array}{l}\text { Total } \\
\text { Cost } \\
\text { (Nu.) }\end{array}$ & $\begin{array}{l}\text { Share of } \\
\text { the Cost } \\
(\%)\end{array}$ \\
\hline \multicolumn{6}{|l|}{ COSTS } \\
\hline A. Fixed Cost & & & & $\mathbf{0}$ & $\mathbf{0}$ \\
\hline \multicolumn{6}{|l|}{ B. Variable Cost } \\
\hline Seed & $\mathrm{Kg}$ & 25 & 40 & 1000 & 1.94 \\
\hline FYM & MT & 1 & 1000 & 1000 & 1.94 \\
\hline Fertilizer & Pkts & 2 & 220 & 440 & 0.86 \\
\hline Butachlor & Pkts & 1 & 370 & 370 & 0.72 \\
\hline Tools & Lumpsum & 1 & 700 & 700 & 1.36 \\
\hline Land Tax & Acre & 1 & 24 & 24 & 0.05 \\
\hline \multicolumn{4}{|c|}{ B1: Total Material Cost (Nu. /Acre) } & 3534 & \\
\hline B2: Labour Cost & Man-days & 88 & 450 & 39600 & 76.99 \\
\hline \multicolumn{6}{|l|}{ B3: Average Energy } \\
\hline $\begin{array}{l}\text { Cost (Hiring } \\
\text { machines/draught) }\end{array}$ & Nu. /Acre & 1 & 7050 & 7050 & 13.71 \\
\hline B4: Milling charge & Quintal & 12.5 & 100 & 1250 & 2.43 \\
\hline \multicolumn{4}{|c|}{ Total Cost B1+B2+B3+B4 (Nu/Acre) } & 51434 & \\
\hline
\end{tabular}

Table 4: Return Analysis

\begin{tabular}{lllll}
\hline RETURN & Unit & Quantity & $\begin{array}{l}\text { Price } \\
\text { (Nu/Quantity) }\end{array}$ & Total \\
\hline $\begin{array}{l}\text { Total Return (TR) } \\
\text { (paddy) }\end{array}$ & $\mathrm{Kg}$ & 1250 & & \\
$\begin{array}{l}\text { TR (Rice) @ } \\
\text { milling recovery }\end{array}$ & $\mathrm{MT}$ & 750 & 70 & 52500 \\
$\begin{array}{l}\text { Gross Margin (TR- } \\
\text { VC) }\end{array}$ & $\mathrm{Nu}$ & & 1066 \\
$\begin{array}{l}\text { Break even for } \\
\text { production level }\end{array}$ & $\mathrm{Kg}$ & & 735 \\
$\begin{array}{l}\text { Break-even for } \\
\text { price }\end{array}$ & $\mathrm{Nu}$ & & 69 \\
B:C Ratio & & & 1.021 \\
\hline
\end{tabular}


International Journal of Agriculture and Environmental Research

ISSN: 2455-6939

Volume: 06, Issue: 06 "November-December 2020"

\subsection{MEASURES TO INCREASE MARGINAL RETURN}

\subsubsection{Reduce labour requirement}

Total cost and gross return are the determinants of the gross margin. Study shows that rice cultivation is labour intensive and $77 \%$ of the expenditure is incurred on labour. The study conducted by Chhogyel et al., (2015) reported that farm mechanization has the potential to reduce the cost of production by about $10-20 \%$. A similar study conducted by Barman \& Deka (2019) in rice and Rahman et al., (2011) in wheat also reported a reduction of human labour cost through the mechanization of farming. On contrary, only $23.3 \%$ and $30.5 \%$ of farmers of Samtse and Sarpang respectively were found employing farm machinery. However, Yeshey (2012) found high labour cost (121 mandaysacre ${ }^{-1}$ ) even under the mechanization of rice cultivation because of the nature and operation costs of certain activities such as nursery operations and weeding. Hence comprehensive studies must be conducted on locally suitable labour-saving technologies and explore low labour requirement rice planting techniques. For instance, the study on the effect of different planting methods on rice conducted at Agriculture Research and Development Center, Samtenling (Sarpang) showed that direct seeded paddy cultivation as a potential method to reduce the cost of labour without compromising yield (Dendup et al, 2018). Therefore, it is imminent to reduce the labour requirement in rice cultivation to reduce the overall cost of cultivation. Further, adaptive study and promotion of small labour-saving machinery such as transplanter, weeder, reaper, and thresher are vital in curbing the production cost of small rice farmers in Southern Bhutan.

\subsubsection{Increase Return}

The study recorded that average rice productivity in southern Bhutan at 1.25 tonnesacre $^{-1}$ against that of 1.7 tonnesacre $^{-1}$ at the national level (Agriculture statistics, 2017, 2018, 2019). The low productivity in districts under study may be due to poor plant and soil management as evidenced through the limited use of agrochemicals like fertilizer (3.5\%), weedicides (10.75\%), and plant protection chemicals $(0.65 \%$. Despite the limited use of agrochemicals, on average, only 1 tonne FYMacre $^{-1}$ was used against the recommended rate of 2-3tonnesacre ${ }^{-1}$. (A Guide to Fertilizer Recommendation for Major Crops, 2008). Ghimiray et al., (2013) also reported poor soil and plant management, despite humid and high temperatures favoring the incidence of disease and insect pests and also receiving high rainfall causing nutrient leaching from prominent sandy loam soils of southern Bhutan which is not replenished for higher rice productivity. Shrestha (2004); Ghimiray, Wangdi, Chettri, Bocke \& Punjabi, (2006) observed that the adoption of improved management such as the application of inorganic fertilizers improved weed management practices. They further reiterated poor mechanization of rice farming in low altitudes despite having feasible topography as compared to high altitudes. Shrestha (2004), also reported that the 
International Journal of Agriculture and Environmental Research

ISSN: 2455-6939

Volume: 06, Issue: 06 "November-December 2020"

productivity was higher in acres where there was high adoption of high yielding varieties, weedicides, fertilizers and other improved technologies in Bhutan.

Another reason for low productivity could be adopting traditional and low yielding rice varieties. Ghimiray et al., (2013) found overall improved rice varieties adoption at $43 \%$ in the country while that for southern districts at $46 \%$ compared to $17 \%$ in 2003 (Shresthra, 2004).The modern improved varieties showed $26 \%$ yield gain over local varieties in Wangdue-Punakha valley (Chhogyel \& Bajgai, 2015) and Shrestha, (2004) mentioned that modern variety has yield advantage of more than $27 \%$ over traditional varieties. Since 1988, 26 improved varieties were released in the country from which 15 varieties can be cultivated in southern Bhutan $(<1500$ masl). Given limited land resources coupled with rapid urbanization, vertical expansion through development and promotion of improved and high yielding rice varieties is important.

Lack of irrigation and poor irrigation scheduling could be another reason for low productivity. As evidence, on an average, two-man days were employed for irrigation and rice cultivation depends on highly erratic monsoon rain agreeing with Mahesh et al, (2006). However, further study on irrigation and water management in rice cultivation is suggested to validate the finding. Moreover, development of rain fed rice varieties with higher resistant to biotic and abiotic stress would help in with standing global climate change and increase productivity.

\section{Policy Intervention}

Generally, market assessment or analyses of cost production are two basic ways to determine the price of the product but the market is the final determinant (Selvavinayagam K., 1991). Hence, for the price fixation, there is very little scope as it depends on the market forces. However, the policy effect of government assistance on rice farming such as incentives, states price control, compensation and subsidies may help in making rice farming enterprises attractive. For example, reduction in taxes, political liberation, and abandonment of the state's price control had led to an increase in rice production in Vietnam, Thailand, and the Philippines (Laiprakobsup, 2019). Whereas in Bhutan, besides providing little facilitation and subsidies in inputs like seed, fertilizers, and chemicals, the wetland tax is not waived, there is no crop insurance policy and marketing incentives which may help make rice farming a profitable venture.

On other hand, the study conducted in Malaysia by (Kari, 2018) however, reported degradation of soil quality due to increased use of fertilizers when fertilizer was subsidized. Similarly, farm machinery subsidy in Bhutan was reported counterproductive to lower-income compared to that of higher income groups, and also non-poor availed a larger share of subsidies (Wang et al., 2019). Therefore, it is imperative to have a pleasing policy that is inclusive, sustainable, and holistic especially on subsidies, compensation, and incentives in Bhutan to augment the rice growers. 
International Journal of Agriculture and Environmental Research

ISSN: 2455-6939

Volume: 06, Issue: 06 "November-December 2020"

\section{SENSITIVITY ANALYSIS}

Table 5: Percentage change in $\mathrm{BC}$ under the simulated situation

\begin{tabular}{|c|c|c|c|c|c|c|c|c|}
\hline \multirow[t]{2}{*}{ Parameters } & $\begin{array}{l}\text { Increase } \\
\text { by } 5 \%\end{array}$ & $\begin{array}{l}\text { Increase } \\
\text { by } 10 \%\end{array}$ & $\begin{array}{l}\text { Increase } \\
\text { by } 15 \%\end{array}$ & $\begin{array}{l}\text { Increase } \\
\text { by } 2 \%\end{array}$ & $\begin{array}{l}\text { Decrease } \\
\text { by } 5 \%\end{array}$ & $\begin{array}{l}\text { Decrease } \\
\text { by } 10 \%\end{array}$ & $\begin{array}{l}\text { Decrease } \\
\text { by } 15 \%\end{array}$ & $\begin{array}{l}\text { Decrease } \\
\text { by } 20 \%\end{array}$ \\
\hline & \multicolumn{8}{|c|}{ Percentage Change in BC Ratio } \\
\hline Productivity & 5.1 & 10.2 & 15.3 & 20.4 & -5.1 & -10.2 & -15.3 & -20.4 \\
\hline $\begin{array}{l}\text { Output } \\
\text { price }\end{array}$ & 5.1 & 10.2 & 15.3 & 20.4 & -5.1 & -10.2 & -15.3 & -20.4 \\
\hline Labor wage & -3.8 & -7.3 & -10.6 & -13.6 & 4.1 & 8.5 & 13.3 & 18.6 \\
\hline $\begin{array}{l}\text { Labor } \\
\text { requirement }\end{array}$ & -3.8 & -7.3 & -10.6 & -13.6 & 4.1 & 8.5 & 13.3 & 18.6 \\
\hline $\begin{array}{l}\text { Subsidy on } \\
\text { material } \\
\text { cost }\end{array}$ & 0.4 & 0.7 & 1.1 & 1.4 & -0.3 & -0.7 & -1.0 & -1.4 \\
\hline
\end{tabular}

Note: Material cost includes Seeds, FYM \& fertilizers, PP Chemicals, tools, and land tax

The sensitivity analysis shows that the $\mathrm{BC}$ ratio is very sensitive to the change in productivity or change in the selling price of rice followed by the change in labor requirement or wage rate. Amongst all the factors, subsidy on materials cost shows the lowest percentage change in benefit-cost ratio. This indicates that change in productivity or output price would have the highest impact on the gross margin compared to other parameters but a change in subsidy on cost materials would make only a small difference in gross return. Considering price and wage rate to be determined by the market force, effort must be directed either to increase productivity or to reduce the labour required to maximize the gross margin. On other hand, providing subsidy on materials costs like current practice would help very little in increasing the gross margin. Therefore, to increase the gross margin, attention must be paid either to the mechanism that enhances productivity or reduces the labor requirement.

\section{CONCLUSIONS AND RECOMMENDATIONS}

Rice farming in southern Bhutan shows a low gross margin $\left(\right.$ Nu.1066acre $\left.{ }^{-1}\right)$ and is labour intensive under the current cultivation practices. This could be due to the high cost of production coupled with low productivity. Despite feasible topography of mechanizing most operations of rice farming, only a few sections of the farmers use farm machinery. Investment in farm mechanization and exploring alternative measures to reduce labour requirements must be 
International Journal of Agriculture and Environmental Research

ISSN: 2455-6939

Volume: 06, Issue: 06 "November-December 2020"

acknowledged. On other hand, there is scope to increase production through the adoption of improved varieties, adoption of recommended package of practices such as manure and fertilizer application, plant health, and weed management. It is unfair to mention that farmers haven't adopted the recommended package of rice cultivation practices with comprehensive study, but technologies introduction, invention, and intervention must be aligned to the farmer's priority and preferences by making efforts of agricultural researches farmer inclusive and participatory. It is also very crucial that research and development in rice farming to identify the choices and challenges of farmers to maximize the return from limited resources. On the other hand, policy interventions such as subsidies, compensation, and incentives must be strengthened or instituted to make rice farming lucrative. Rice farming in Bhutan is not merely about its economic importance but also about national food security and sufficiency concern. The study also recommends a similar temporal and spatial study in all the regions of Bhutan to understand the production economics and profitability to assist in deciding strategies to make rice farming more profitable.

\section{ACKNOWLEDGEMENT}

The authors remain indebted to ARDC Samtenling colleagues who were involved in conducting survey and collecting information.

\section{REFERENCES}

Chhogyel, N., Ghimiray, M., Wangdue, K., \& Bajgai, Y. (2015). Enhancing Bhutanese Rice in the Domestic Market through increased Production and Favorable Pricing Regime. Journal of Bhutan Studies, 32(November), 26-44.

Department of Agriculture,Ministry of Agriculture and Forests, Royal Government of Bhutan. (2020). Cost of production for field and horticulture Crops in Bhutan.

Department of Revenue and Customs, Ministry of Finance, Royal Government of Bhutan. (2019). Bhutan Trade Statistics 2019.

Dillon, C. R. (1993). Advanced breakeven analysis of agricultural enterprise budgets. Agricultural Economics, 9(2), 127-143. https://doi.org/10.1016/0169-5150(93)90008-Z

RNR Statistics Division, Ministry of Agriculture and Forests,Royal Government of Bhutan. (2017-2019a). Bhutan RNR Statistics.

RNR Statistics Division, Ministry of Agriculture and Forests, Royal Government of Bhutan. (2017-2019b).Agriculture statistics. 
International Journal of Agriculture and Environmental Research

ISSN: 2455-6939

Volume: 06, Issue: 06 "November-December 2020"

Ghimiray, M., Pandey, S., \& Velasco, M. L. (2013). Tracking of Improved Varieties in South Asia Bhutan Report on Rice Estimating adoption rate of modern rice varieties in Bhutan. August, 1-23.

Kari, F. (2018). Evaluation of Agricultural Subsidies and Welfare of Rice Farmers. Kuala Lumpur: IDEAS Policy Research Berhad

Laiprakobsup, T. (2019). The policy effect of government assistance on rice production in Southeast Asia: Comparative case studies of Thailand, Vietnam, and the Philippines. Development Studies Research, 6(1), 1-12. https://doi.org/10.1080/21665095.2019.1568900

National Statistics Bureau of Bhutan, Royal Government of Bhutan. (2017). Living Standards Survey.

Manikandan, M., Mani, N., \& Karthikeyan, P. (2018). Cost and return of paddy cultivation in Erode district, Tamil Nadu. ORYZA- An International Journal on Rice, 55(3), 484. https://doi.org/10.5958/2249-5266.2018.00059.0

NCHM, Royal Government of Bhutan. (2017). Bhutan State of the Climate 2017. http://nchm.gov.bt/attachment/ckfinder/userfiles/files/Bhutan State of the Climate 2017.pdf

Res, J. R., Pathok, P., \& Deka, N. (2019). Rice Research: Open Access Dynamics of Costs, Returns, and Prices of Paddy in Assam, India. 7(3), 3-7.

National Statistics Bureau of Bhutan, Royal Government of Bhutan. (2017). Population \& Housing Census of Bhutan.

Suwanmaneepong, S., Kerdsriserm, C., Lepcha, N., Cavite, H. J., \& Llones, C. A. (2020). Cost and return analysis of organic and conventional rice production in Chachoengsao Province, Thailand.Organic Agriculture, 10(3), 369-378. https://doi.org/10.1007/s13165020-00280-9

National Soil Services Center, Ministry of Agriculture and Forest, Royal Government of Bhutan (2009). A guide to fertilizer recommendation guide for major crops.

Wang, S. W., Manjur, B., Kim, J. G., \& Lee, W. K. (2019). Assessing socio-economic impacts of agricultural subsidies: A case study from Bhutan. Sustainability (Switzerland), 11(12). https://doi.org/10.3390/SU11123266

Dorji, Y., Tamang, M., \& Vernoy. (2015). The history of the introduction and adoption of important food crops in Bhutan.Thimphu: National Biodiversity Center, MoAF. 
International Journal of Agriculture and Environmental Research

ISSN: 2455-6939

Volume: 06, Issue: 06 "November-December 2020"

Ghimiray, M., Panday, S., \& Velasco, L. (2013). Estimating adoption rate of modern rice varieties in Bhutan: Tracking of Improved Varieties in South Asia. Bhutan Report on Rice.

Department of Agriculture,Ministry of Agriculture and Forests, Royal Government of Bhutan. (2020). CInventory of Released and De-notified Crops in Bhutan (1988-2020).

Shrestha, S. (2004). An economic impact assessment of the rice research program in Bhutan. An economic impact assessment of the rice research program in Bhutan Report.

Department of Agriculture,Ministry of Agriculture and Forests, Royal Government of Bhutan. (2020). Twelfth Five Year Plan 2018-2023.Thimphu, Department of Agriculture.

Yeshey., Ghimiray, M., \& Bajgai, Y(2014).Effects of Mineral Fertilizers on Rice productivity in Wangdue-Punakha Valley: Journal of Renewable Natural Resources Bhutan (Vol.10). Council for RNR Research of Bhutan, Ministry of Agriculture and Forests.

Ghimiray, M. (2012).An analysis of rice varietal improvement and adoptionrate by farmers in Bhutan: Journal of Renewable Natural Resources Bhutan. (Vol. 8). Council for RNR Research of Bhutan, Ministry of Agriculture and Forests.

Yeshey.(2012).Economics of mechanizing rice cultivation at RNRRDC Bajo: Journal of Renewable Natural Resources Bhutan. (Vol. 8). Council for RNR Research of Bhutan, Ministry of Agriculture and Forests.

Chhogyel, N., \& Bajgai, Y. (2015). Modern rice varieties adoption to raise productivity: Case study of two districts in Bhutan: SARRC Journal of Agriculture. (Vol.13).SAARC Agricultural Centre, Bangladesh

Ghimiray, M., Wangdi, K.,Chhetri, B.G., Bockel, L., \&Panjabi, M.(2006).Rice Chain Analysis: Commodity chain analysis report. Thimphu: Department of Agriculture, Ministry of Agriculture, and Forests. 